\title{
The Protective Role of Simvastatin on Methotrexate-Induced Bone Injury in Adult Albino Rat
}

\section{Original Article}

\author{
Amgad Gaber Elsaid and Ahmed S. Sadek
}

Department of Anatomy and Embryology, Faculty of Medicine, Ain Shams University, Egypt

\begin{abstract}
Background: Methotrexate (MTX) is a folic acid antagonist and chemotherapeutic agent widely used in cancer treatment. It is used as first line therapy in treatment of rheumatoid arthritis (RA). MTX was known to cause bone defects in the form of reduced mineral density (BMD) and bone fractures. Simvastatin (SIM) is widely used for cardiovascular diseases.

Aim of Work: To investigate the possible protective role of SIM on MTX induced bone injury in rats.

Material and Methods: Forty adult male albino rats were divided into four groups; Control group, SIM-treated group, MTX group and MTX + SIM group. MTX was given by subcutaneous injection as $0.65 \mathrm{mg} / \mathrm{kg} / \mathrm{day}$ for two separate 5 days. SIM was administered orally as $25 \mathrm{mg} / \mathrm{kg}$ /day one month prior to and during the MTX course. At the end of the experiment, blood samples were collected for levels of osteocalcin (OSC) and alkaline phosphatase (ALP). All rats were sacrificed and specimens from their femurs were examined.

Results: examination of MTX group showed marked thinning of the periosteum, and widening of bone marrow spaces. There was an apparent decrease in the number of osteocytes, together with an apparent increase in the number of osteoclasts. There was a significant decrease in the serum level of OSC together with a highly significant increase in the serum level of ALP in the MTX group as compared to the control group. On administration of SIM with MTX, there was marked improvement in most of the histological and serological parameters.

Conclusion: SIM could be used as a protective measure for MTX-induced bone defects.
\end{abstract}

Key Words: chemotherapeutic, Statins, osteomodulator, osteocalcin, bone resorption.

Received: 20 May 2016, Accepted: 30 April 2017

Corresponding Author: Amgad Gaber Elsaid, Tel.: 01006042491, E-mail: amgadana@yahoo.com.

ISSN: 1110-0559, March 2017, Vol. 40, No. 1

\section{INTRODUCTION}

The use of chemotherapy to treat cancer began at the start of the twentieth century ${ }^{[1]}$. Both clinical and animal studies reported that chemotherapy can cause adverse effects on bone, mainly on bone remodeling and bone $\operatorname{mass}^{[2]}$.

Methotrexate (MTX) is a folic acid antagonist and chemotherapeutic agent widely used in cancer treatment ${ }^{[3]}$. It is the most commonly used anti-metabolite agent for childhood cancers, and it was proved to be effective in other malignancies such as choriocarcinoma and osteogenic sarcoma $^{[4,5]}$. MTX is used as first line therapy in treatment of rheumatoid arthritis (RA) and other inflammatory diseases such as psoriasis and dermatomyositis ${ }^{[6]}$.
Although MTX was proved to be effective in the treatment of both RA and many cancers, discontinuation is common due to occurrence of its adverse effects ${ }^{[7]}$. There are many evidences that low dose of MTX can reache high concentration in bone as reported by Bologna et al., who found that MTX concentration in cortical and trabecular bone was 13 and 11.5 fold higher than plasma concentration of same drug ${ }^{[8]}$. MTX was known to cause bone defects in the form of fractures and bone ingrowth defects especially in pediatric patient ${ }^{[9]}$. High MTX doses could contribute to bone growth impairment, reduced bone mineral density $(\mathrm{BMD})$ and bone fractures ${ }^{[10,11]}$. Osteoporotic fractures associated with MTX treatment were reported for the first time in 1970 in patients treated with a high dosage of MTX for acute leukemia. This "MTX osteopathy" was characterized by osteoporosis, bone pain, and compression 
fractures $^{[12]}$. Also, women given chemotherapy consisting of MTX for breast and ovarian cancers may suffer from bone $\operatorname{loss}^{[13]}$.

In addition, due to increased usage of anti-cancer drugs and their significant effect on skeletal health, it becomes important to explore potential supplementary treatments that may be useful in protecting bone during cancer chemotherapy ${ }^{[14]}$. Folinic acid, soy products rich in isoflavone, genistein, and fish oils rich in omega-3 polyunsaturated fatty acids were previously used to improve bone health ${ }^{[15-18]}$.

Statins are best known as competitive inhibitors of hydroxyl-methyl-glutaryl-CoA (HMG-CoA) reductase that reduce cholesterol synthesis, therefore they are widely used for the treatment of hypercholesterolemia ${ }^{[19]}$. Pacheco-Pantoja and Alvarez-Nemegyei assumed that the use of statins in the treatment of metabolic bone diseases in humans has not yet reached the status of solid scientific dogma, even though it had been about fifteen years since the first experimental evidence in an animal model of the osteomodulador effect of statins was reported by Mundy et al..$^{[20,21]}$

This study aimed to investigate the possible protective role of Simvastatin on MTX induced bone injury in adult male albino rats.

\section{MATERIAL AND METHODS}

\section{- Animals}

Forty adult male albino rats of the Sprague Dawely strain obtained from the animal house of Medical Research Centre, Faculty of Medicine, Ain Shams University. They were aged 46- months with average weight 200- 250 gm. All rats were bred and provided with food and water. All animal procedures were performed in accordance with the recommendations for the proper use and care of laboratory animals.

\section{- Drugs}

MTX vial was obtained from EIMC United Pharmaceuticals Company, Cairo-Egypt. The dose was calculated as $0.65 \mathrm{mg} / \mathrm{kg} /$ day for two separate 5 days courses ( 5 days on/9 days off), and given by subcutaneous injection ${ }^{[4]}$.

SIM was obtained in the form of tablet (Zocor ${ }^{\circledR}$, MSD). The dose was $25 \mathrm{mg} / \mathrm{kg} /$ day orally by gastric tube for 2 months ${ }^{[22]}$.

\section{- Experimental Design}

Animals were divided into four groups; control group (Group $\mathrm{A} ; \mathrm{N}=5$ ), SIM-treated group (Group $\mathrm{B} ; \mathrm{N}=5$ ),
MTX group (Group $\mathrm{C} ; \mathrm{N}=15$ ) and MTX + SIM group (Group D; N=15). SIM (25 mg/kg/day) was administered orally by gastric tube one month prior to and during the MTX course. At the end of the experiment, blood samples were collected and serum levels of osteocalcin (OSC) and alkaline phosphatase (ALP) were determined. The animals were sacrificed and femurs were dissected free of soft tissue, washed with saline. Upper ends (including the proximal part of metaphysis) were cut and fixed immediately in glutaraldehyde at $4^{\circ} \mathrm{C}$ for 24 hours. Undecalcified sections were obtained by dehydrating the bones in acetone for 36 hours, followed by immersion in xylene for 24 hours. Thereafter, the bones were embedded in methyl methacrylate for 3 days. $10 \mu \mathrm{m}$ Sections were cut by a Polycut $\mathrm{S}$ microtome (Reichert-Jung microtome, Model 2050, Leica, Deerfield, IL, USA) ${ }^{[23]}$. Sections were then stained with Haematoxylin and Eosin ${ }^{[24,25]}$. Bcl-2 used for immunohistochemical analysis. Immunohistochemical staining for Bcl-2

Formalin-fixed and paraffin-embedded bone sections were de-waxed in xylene and then dehydrated with a graded ethanol series. Endogenous peroxidase was inactivated by incubation in $3 \% \mathrm{H} 2 \mathrm{O} 2$ for ten minutes. Sections were placed in citrate buffer for antigen retrieval by microwave heating. Non-specific binding was blocked by incubation in goat serum, and then sections were incubated with rabbit anti-Bcl-2 polyclonal antibodies (1:100; Santa Cruz Biotechnology, Santa Cruz, CA, USA). After three washes in phosphate buffer saline (PBS) for 15 minutes, the slides were incubated with the appropriate secondary antibody at room temperature for 30 minutes. Avidinbiotin- peroxidase complex was used to amplify the reactions, and 3, 3'- diaminobenzidine hydrochloride/ H2O2 (Sigma Aldrich Co.) to develop them. The sections were finally counterstained with hematoxylin. Under the optical microscope (Olympus, Tokyo, Japan) brown particles or patches seen in the cytoplasm indicated positive staining ${ }^{[26]}$.Statistical analysis

The mean serum levels of OSC and ALP of all the studied groups of rats were presented as mean and standard deviation, and were compared using Student's t-test. The level of statistical significance was defined as $P \leq 0.05$ where Scheffe's multiple comparison was used to indicate the significant differences among all the studied groups. The statistical analysis of data was carried out using Excel and statistical package for the Social Science Software, version 11 (SPSS, Inc., Chicago, USA.) on an IBM compatible computer ${ }^{[27]}$.

\section{RESULTS}

\section{Histological Findings}

Examination of bone sections from the control group and SIM-treated group (Groups A \& B) showed similar results. Under the periosteum, bones were formed of 
outer shell of compact bone and inner trabeculae of cancellous bone (Fig. 1). The periosteum was formed of an outer fibrous layer and an inner osteogenic layer. The outer fibrous layer was formed of dense collagen fibers with fibroblasts in between, and the inner osteogenic layer was made up of spindle shaped osteoprogenitor cells. The sub-periosteal area showed grooves contained osteoprogenitors, osteoblasts, and blood capillaries. The compact bone showed many osteocytes inside the lacunae arranged around centrally located Haversian canals (Fig. 2). The cancellous bone was formed of network of thick branching bone trabeculae composed of irregular bone lamellae and bone marrow spaces between them. Rounded active osteogenic cells were observed lining the bone trabeculae indicating bone formation (Figs $3 \& 4$ )

Examination of sections of bony tissues from MTX group (Group C) showed marked thinning of the periosteum especially the fibrous layer. The outer compact bone showed an apparent decrease in the number of osteocytes as compared to control group. Some osteocytes had wide lacunae and others showed pyknotic nuclei (Figs. $5 \& 6$ ). The inner cancellous bone in most of specimens lost their normal architecture and showed thin widely separated trabeculae and widening of bone marrow spaces. Some trabeculae showed refractile areas indicating bone loss and necrosis. Most of the osteogenic cells linning the trabeculae appeared flat indicating inactive bone formation (Figs. $7 \& 8$ ). Many multinucleated acidophilic osteoclasts were observed at the site of bone resorption lining the irregular bone trabeculae (Fig. 9).

Examination of sections of bone tissues from MTX + SIM group (Group D) showed that the periosteum return nearly to its normal thickness with apparent increase in the number of osteocytes (Fig. 10). The bone trabeculae still thin but the osteoclasts were few as compared to MTX group (Fig. 11).

The control \& SIM-treated groups (Groups A \& B) showed negative reaction to Bcl-2. There waspositive reaction for $\mathrm{Bcl}-2$ in the mesenchymal cellsresponsible for bone formation in the experimentalgroups, which was strong in MTX group (Group C) andweak in MTX + SIM group (Group D) (Figs. 12- 14).

\section{Serological Findings}

The mean OSC and ALP among the studied groups of rats are presented in Table-1. A significant decrease in the serum level of OSC was noticed in the MTX group as compared to both the control and MTX+SIM groups. Also, there was a highly significant increase in the serum level of ALP in both MTX and MTX+SIM groups as compared to the control group.

Table 1: Comparison of serum OSC and ALP among the studied rat groups

\begin{tabular}{|c|c|c|c|c|c|}
\hline Parameters & $\begin{array}{c}\text { Control (Group A) } \\
\text { Mean } \pm \text { SD } \\
(n=5)\end{array}$ & $\begin{array}{l}\text { SIM-treated group } \\
\text { (Group B) } \\
\text { Mean } \pm \text { SD } \\
(\mathrm{n}=5)\end{array}$ & $\begin{array}{c}\text { MTX } \\
\text { group }(C) \\
\text { Mean } \pm \text { SD } \\
(n=15)\end{array}$ & $\begin{array}{c}\text { MTX + SIM } \\
\text { group (D) Mean } \\
\pm \text { SD } \\
(n=15)\end{array}$ & P value \\
\hline $\begin{array}{l}\text { Osteocalcin (OSC) } \\
(\mathrm{ng} / \mathrm{ml})\end{array}$ & $4.515 \pm 0.258$ & $4.42 \pm 0.27$ & $2.428 \pm 0.734$ & $4.112 \pm 1.689$ & $\begin{array}{c}\mathrm{P} 1=0.0361 * \\
\mathrm{P} 2=0.912 \\
\mathrm{P} 3=0.0349 *\end{array}$ \\
\hline $\begin{array}{l}\text { Alkaline } \\
\text { phosphatase (ALP) } \\
(\mathrm{u} / \mathrm{l})\end{array}$ & $140.85 \pm 12.351$ & $140.76 \pm 12.338$ & $250.48 \pm 7 . .979$ & $245.13 \pm 6.079$ & $\begin{array}{c}\mathrm{P} 1=0.002 * * \\
\mathrm{P} 2=0.002 * * \\
\mathrm{P} 3=0.7790\end{array}$ \\
\hline
\end{tabular}

P1: Group A version group C.

* Significant; $P<0.05$.

P2: Group A version group D.

**Highly significant; $P<0.01$.

P3: Group C version group D. 


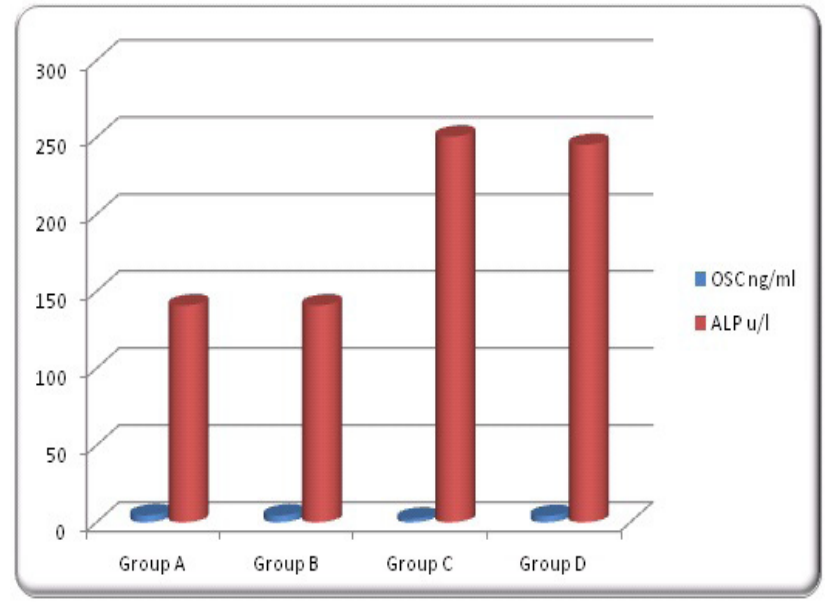

Histogram 1: Serum OSC and ALP among the studied rat groups.

\section{1}

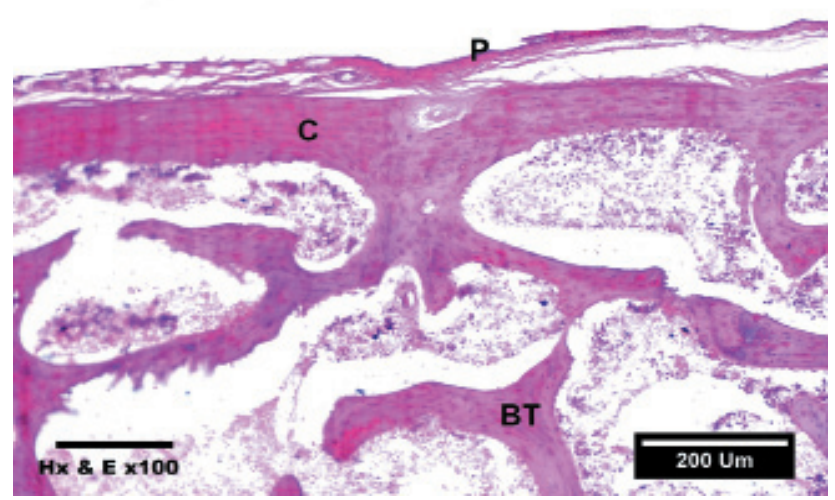

Fig. 1: A photomicrograph of a section of the shaft of femur of a control rat, showing outer shell of compact bone (C), covered by periosteum $(\mathrm{P})$ and inner trabeculae of cancellous bone (BT).

$\mathrm{H} \& \mathrm{E}$ X 100

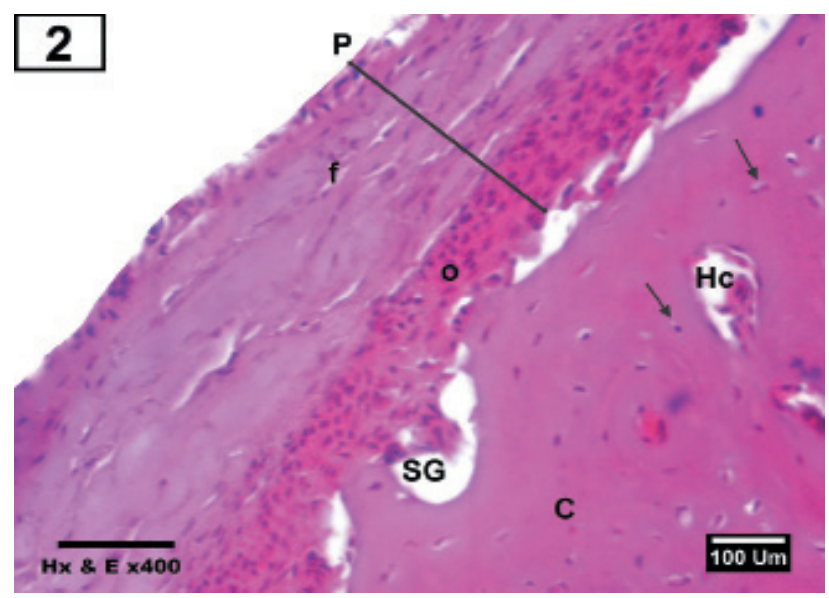

Fig. 2: A photomicrograph of a section of the shaft of femur of a control rat, showing the periosteum $(\mathrm{P})$ formed of an outer fibrous layer (f) and an inner osteogenic layer (o). Note the subperiosteal grooves (SG). Note also osteocytes $(\uparrow)$ inside their lacunae around a centrally located Haversian canal (Hc) in the compact bone (C).

$\mathrm{H} \& \mathrm{E}$ X400

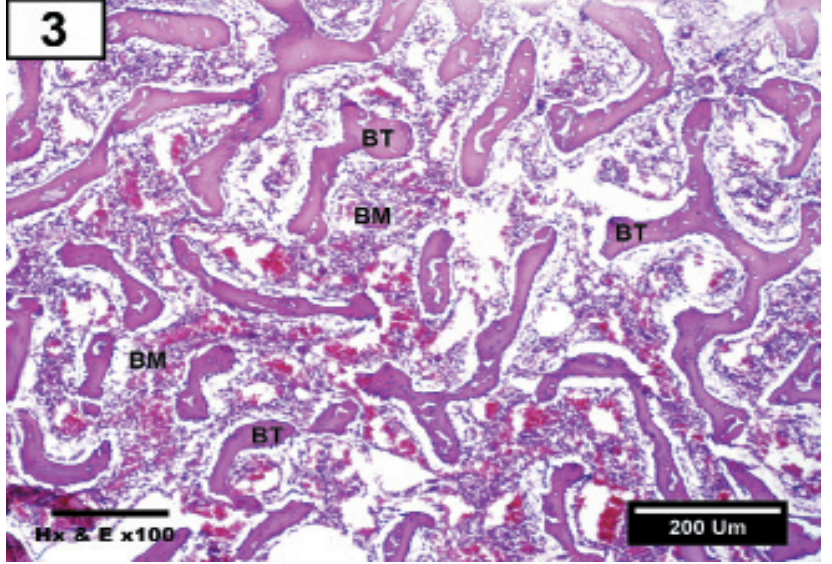

Fig. 3: A photomicrograph of a section of the shaft of femur of a control rat, showing the inner cancellous bone formed of branching bone trabeculae (BT), with bone marrow (BM) spaces in between.

H\&E X 100

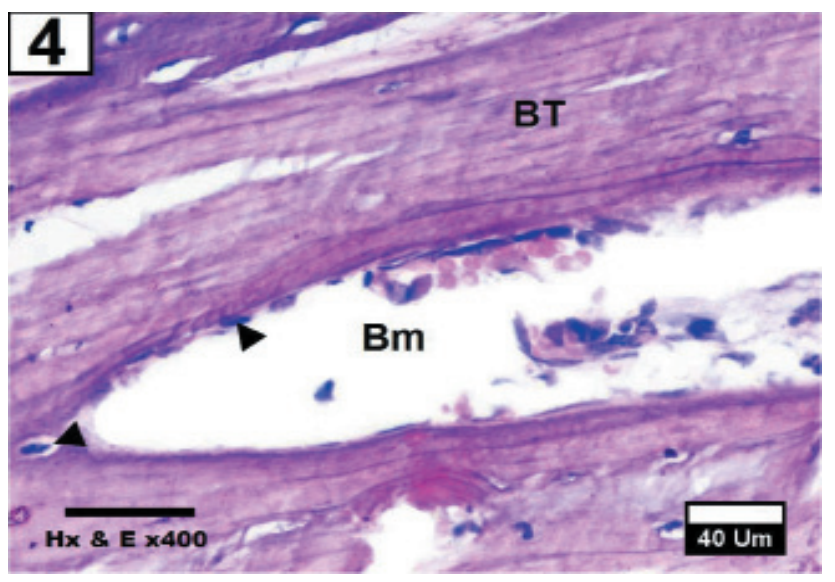

Fig. 4: A photomicrograph of a section of the shaft of femur of a control rat, showing thick branching bone trabeculae (BT) enclosing the bone marrow $(\mathrm{Bm})$ spaces. Note the rounded osteogenic cells lining the trabeculae $(\boldsymbol{\Delta})$.

H\&E X 400

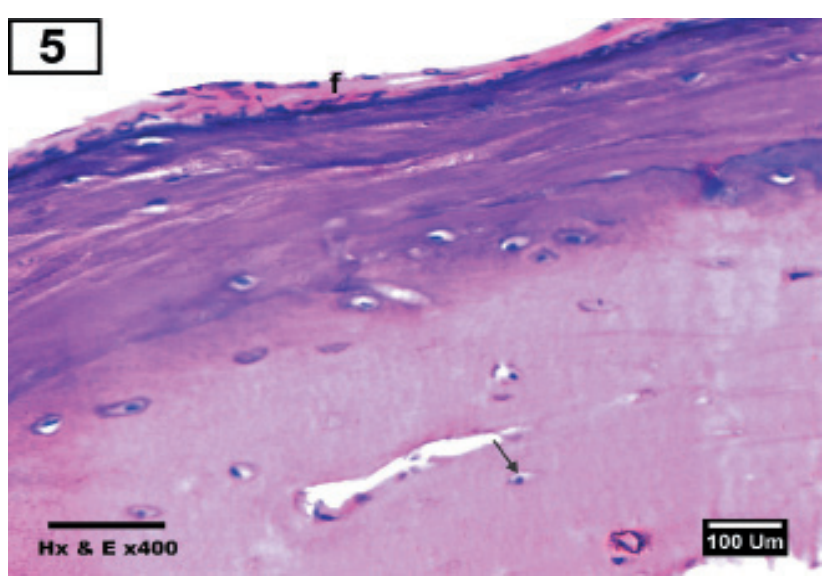

Fig. 5: A photomicrograph of a section of the shaft of femur of a rat of MTX group (C), showing marked thinning of the outer fibrous layer of the periosteum (f). Notice an apparent decrease in the number of osteocytes $(\uparrow)$ compared with that of the control group.

H\&E X 400 


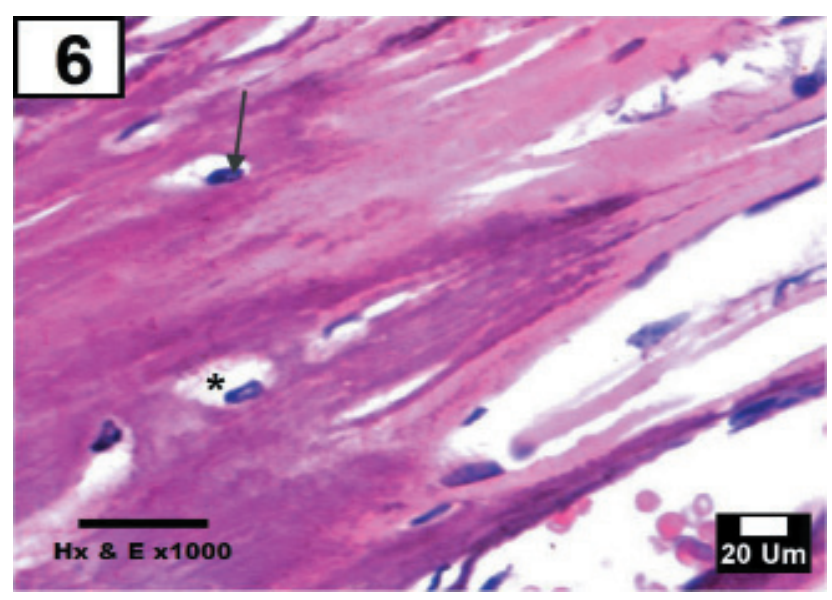

Fig. 6: A photomicrograph of a section of the shaft of femur of a rat of MTX group (C), showing osteocytes had wide lacunae $(*)$. Notice an osteocyte with pyknotic nucleus ( $\uparrow)$. H\&E X 1000

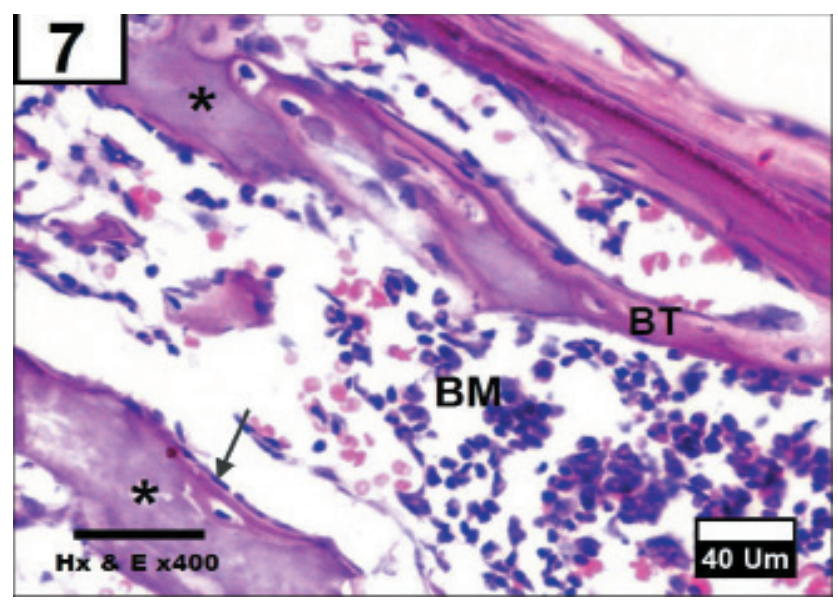

Fig. 7: A photomicrograph of a section of the shaft of femur of a rat of MTX group (C), showing thin bone trabeculae (BT) surrounding wide bone marrow spaces $(\mathrm{Bm})$. Notice refractile areas $(*)$ appeared inside the trabeculae. Note also flat osteogenic cells lining the trabeculae $(\uparrow)$.

H\&E X 400

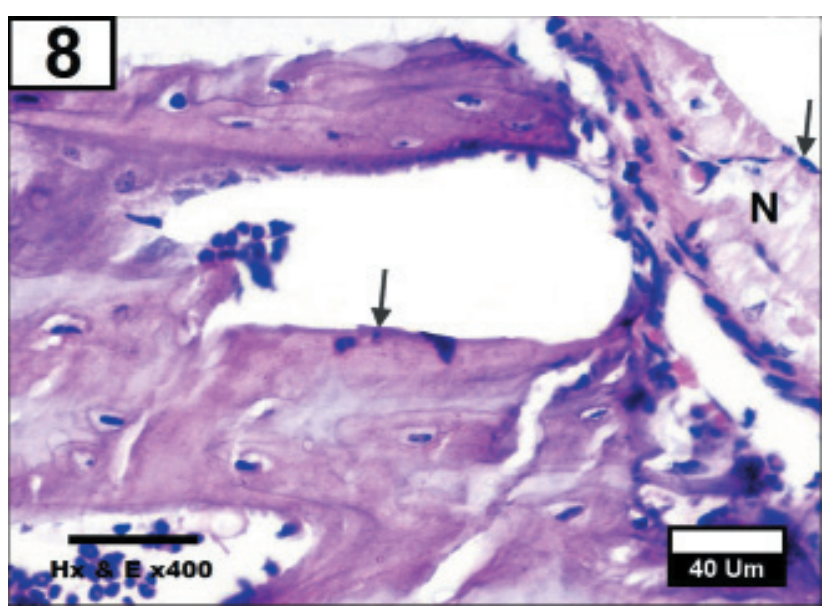

Fig. 8: A photomicrograph of a section of the shaft of femur of a rat of MTX group (C), showing areas of bone necrosis $(\mathrm{N})$ inside the trabeculae. Note flat osteogenic cells $(\uparrow)$ lined the trabeculae.

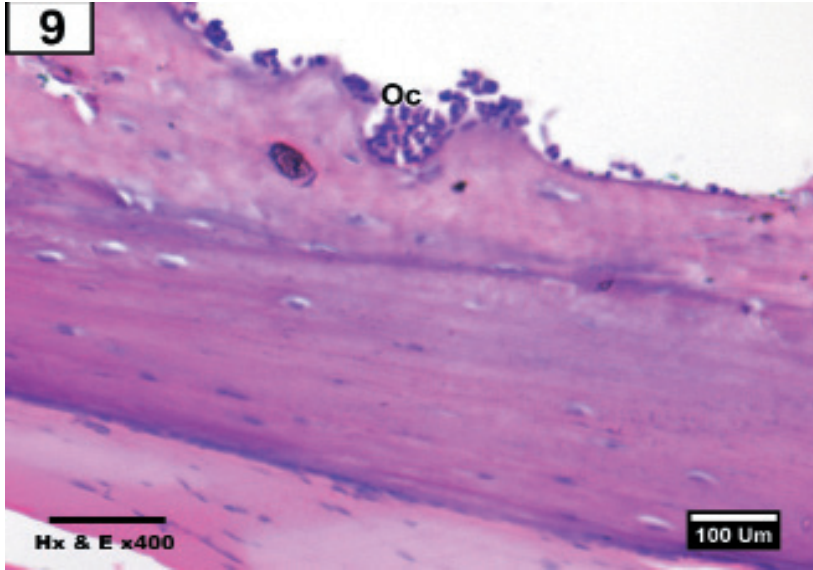

Fig. 9: A photomicrograph of a section of the shaft of femur of a rat of MTX group (C), showing multinucleated acidophilic osteoclasts (Oc) inside cavities at the site of bone resorption.

H\&E X 400

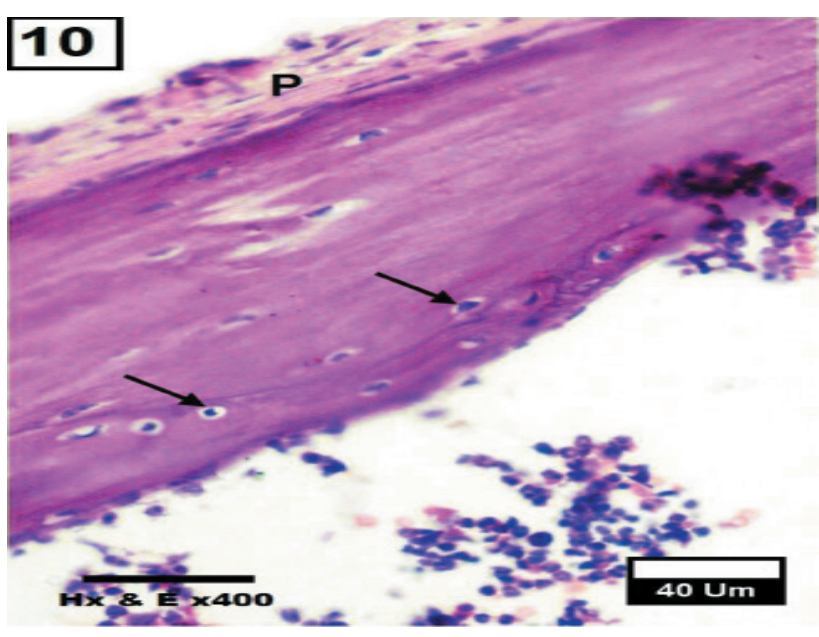

Fig. 10: A photomicrograph of a section of the shaft of femur of a rat of MTX + SIM group (D), showing normal thickness of the periosteum (p), with an apparent increase in the number of osteocytes $(\uparrow)$ compared with that of the MTX group (C).

H\&E X 400

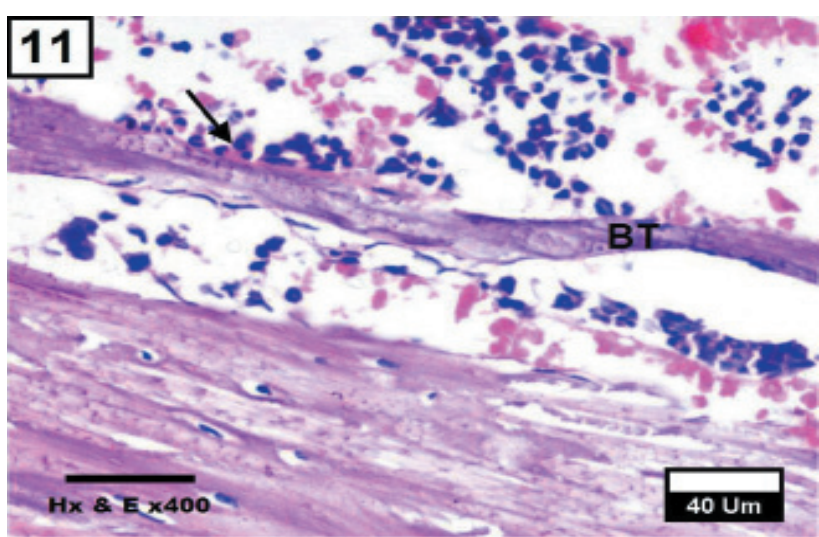

Fig. 11: A photomicrograph of a section of the shaft of femur of a rat of MTX + SIM group (D), showing that the bone trabeculae (BT) still thin but the osteoclasts $(\uparrow)$ were apparently decreased in number as compared to MTX group (C).

$\mathrm{H} \& \mathrm{E}$ X 400 


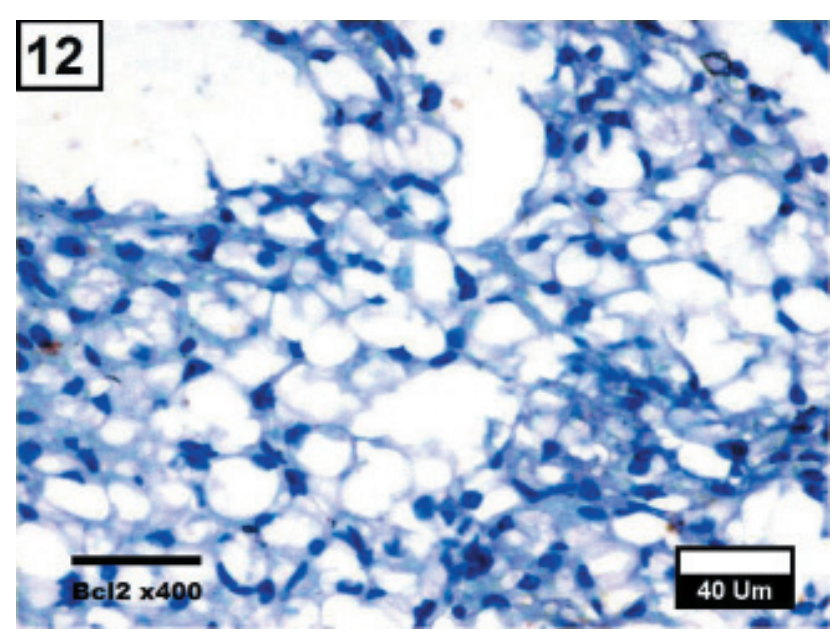

Fig. 12: A photomicrograph of a section of the shaft of femur of a control rat, showing negative reaction to $\mathrm{Bcl}-2$ in the bone marrow.

Bcl-2 X 400

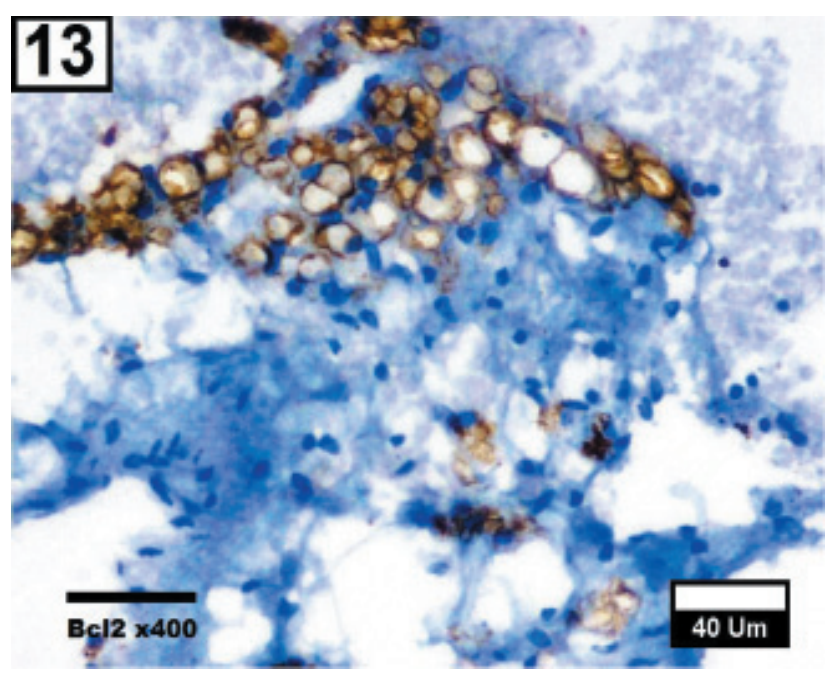

Fig. 13:.A photomicrograph of a section of the shaft of femur of a rat of MTX group (C), showing strong positive reaction to bcl2 in the mesenchymal cells responsible for bone formation in the bone marrow.

Bcl-2 X 400

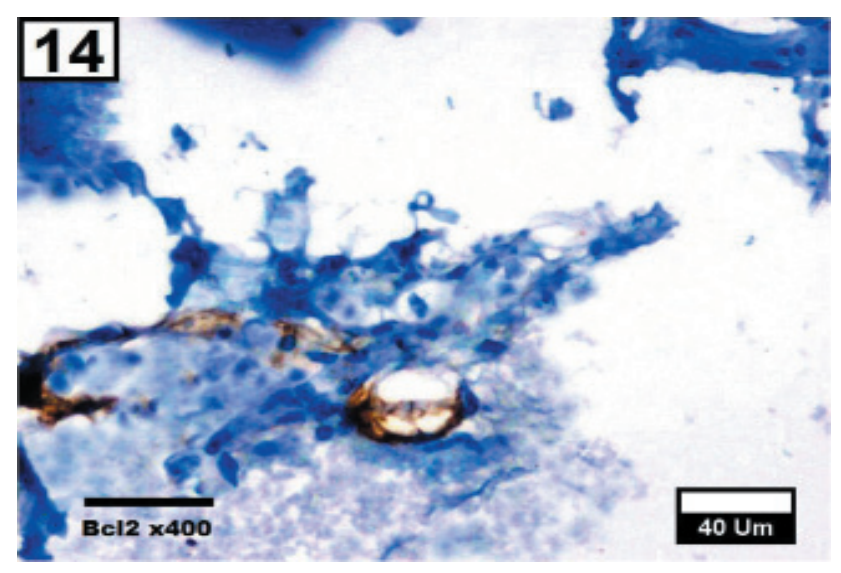

Fig. 14: A photomicrograph of a section of the shaft of femur of a rat of MTX + SIM group (D), showing weak positive reaction to $\mathrm{bcl} 2$ in the mesenchymal cells responsible for bone formation in the bone marrow.

Bcl-2 X 400

\section{DISCUSSION}

MTX, a folate antagonist, is commonly used at high doses for the treatment of malignancies ${ }^{[28]}$. It is associated clinically with bone pain, bone loss, increased fracture risks and osteoporosis which are a serious concern $^{[9,29]}$.

In the present study, sections from the upper end of femur of the control and SIM-treated groups revealed the same histological pattern as described by El-Morsi and his colleagues ${ }^{[30]}$.

In our study, bone affection appeared at cellular level in MTX group (Group C). There was marked thinning of the periosteum specially the fibrous layer. An apparent decrease in the number of osteocytes was observed and some of them showed apoptotic nuclei. Xian et al. attributed the reduction of collagen fibers in the bony cortex to reduction of osteocytes proliferation and induction of osteocytes apoptosis through the Fas/Fas-L death receptor pathway induced by MTX treatment ${ }^{[31]}$.

In the current research, histological examination of the cancellous bone of MTX group showed thin, widely separated bone trabeculae with widening of bone marrow spaces. Previous studies assumed that osteoporosis could be manifested as thinning of bone trabeculae or as removal of some bone trabeculae with remaining trabeculae of normal thickness ${ }^{[30,32,33]}$. Parfitt et al. had reported that bone loss in osteoporosis was initiated by increased depth of erosion cavities, which would lead to focal disruption of the trabeculae, followed by progressive enlargement of the perforations and subsequently, would lead to conversion of the trabecular plates to widely separated rods and bars. This was termed as the button phenomenon and considered as a characteristic feature of osteoporosis ${ }^{[34]}$. Reiner and Bertha described this phenomenon as if the trabeculae were formed of small islands of bone ${ }^{[35]}$. Also, MTX therapy might lead to overall reduction of trabecular bone volume ${ }^{[36]}$. Experimental studies of MTX induced bone defects revealed that apart from the reduced osteoblast number and trabecular bone volume; there was a significant increase in marrow adiposity ${ }^{[31,37]}$.

We found an apparent increase in the number of osteoclasts accompanied with resorptive activity. Noteworthy, Mosekilde et al. considered the increased number of resorptive surfaces as the most dramatic finding in MTX osteoporosis ${ }^{[38]}$. Another possible mechanism for MTX-induced decrease in bone mass is the increased formation of bone resorptive cells (osteoclasts) and the alteration to the bone remodeling balance in favor of bone resorption ${ }^{[39]}$. 
SIM is widely used for cardiovascular diseases ${ }^{[40]}$. However, statins have pleiotropic therapeutic effects including vasodilatory, antithrombotic, antioxidant, anti-inflammatory, and immunosuppressive actions ${ }^{[41]}$. Mundy was first reported statins as potent stimulators of bone formation invitro. Here, we further demonstrate the protective effect of SIM on a rat model of MTXinduced bone injury ${ }^{[21]}$.

Histological findings of bony sections from MTX + SIM group (Group D) showed that the periosteum retained its normal thickness with an apparent increase in the number of osteocytes in the bone lamella, together with decreased number of osteoclasts as compared to MTX group. These findings were in coincidence with Hanayama et al., where Fluvastatin significantly attenuated osteoclast differentiation and activation through a blockade of the classical mevalonate pathway and an antioxidant action, leading to prevention of osteoporosis ${ }^{[42]}$. Similarly, Moon et al. proved that SIM acted as an osteoclastogenesis inhibitor by suppressing reactive oxygen species-mediated signaling pathways. Therefore, SIM has both anti-catabolic and anabolic effect on bone metabolism ${ }^{[43]}$. The potential positive effect of statins on bone formation can be explained by three mechanisms; (a) Promotion of osteogenesis. (b) Suppression of apoptosis of osteoblasts. (c) Inhibition of osteoclastogenesis ${ }^{[44]}$

On the other hand, Reid and Hague looked retrospectively at 9014 patients treated by pravastatin for ischemic heart disease and found no significant effect of statins on fracture risk or BMD when analyzed after follow-up of 6 years ${ }^{[45]}$.

The Bcl-2 gene encodes a protein located in the nuclear membrane, on the inner surface of mitochondria, and the endoplasmic reticulum. This gene has been reported to prolong the survival of cells by specifically inhibiting apoptosis ${ }^{[46]}$. Moreover, the Bcl-2 protein plays an important role in preserving stem cells ${ }^{[47] .}$ In the current work, bone sections of the MTX group (Group C) showed strong positive staining for the anti-apoptotic $\mathrm{Bcl} 2$ protein that is supposed to be increased in case of bone injury to protect the mesenchymal cells responsible for bone formation in the bone marrow by inhibiting apoptosis. On the other hand, SIM administration with MTX could inhibit apoptosis indicated by weak staining for Bcl-2 in the control group. In context, MTX induced apoptosis at days 1 and 2 after MTX treatment, as judged by morphological criteria and TUNEL staining ${ }^{[48]}$. Similarly, apoptosis analysis by insitu nick translation labeling revealed that MTX treatment induced apoptosis among osteoblasts in bone metaphysis ${ }^{[39]}$.
OSC, synthesized in the skeleton is considered a highly sensitive marker for bone formation ${ }^{[49]}$.

We found a significant decrease in serum OSC in the MTX group compared to the control and MTX+SIM groups. In context, serum levels of OSC were significantly lower in the patients with postmenopausal osteoporosis than in the control subjects ${ }^{[50]}$. On the contrary, Watanabe et al. investigated the effects of fluvastatin on patients treated for hypercholesterolemia over a period of one year and found that serum OSC did not change even after a year ${ }^{[51]}$.

ALP, a non specific bone formation marker, is present in all tissues throughout the entire body, but particularly concentrated in liver, bile duct, kidney, bone, intestinal mucosa and the placenta ${ }^{[52,53]}$. Patel et al. noticed a highly significant increase in the level of ALP in MTX-treated rats which is consistent with our findings. Such significant increase in ALP may be attributed to damage of the body tissues by MTX resulting in liberation of ALP in serum ${ }^{[54]}$.

\section{CONCLUSION}

SIM could be considered as an effective treatment for MTX-induced bone defects. However, this needs more studies with appropriate experimental designs, sample sizes suitable for relevant results and analysis.

\section{CONFLICT OF INTEREST}

There are no conflicts of interest.

\section{REFERENCES}

1. De Vita, V. and Chu, E. 2008. A history of cancer chemotherapy. Cancer Res. 68(21): 8643- 53.

2. Fan, C., Cool, J.C., Scherer, M.A., Foster, B.K., Shandala, T., Tapp, H. and Xian, C.J. 2009. Damaging effects of chronic low-dose methotrexate usage on primary bone formation in young rats and potential protective effects of folinic acid supplementary treatment. Bone 44: 61 -70.

3. Schornagel, J.H. and McVie, G. 1983. The clinical pharmacology of methotrexate. Cancer Treatment Review 10: 53- 75.

4. Fan, C., Foster, B., Hui, S. and Xian, C. 2012. Prevention of bone growth defects, increased born resorption and marrow adiposity with folinic acid in rats receiving long-term methotrexate. Plos One J. 7(10): $1-11$. 
5. Mazzantini, M. and Di-Munno, O. 2000. Methotrexate and bone mass. Clin. and Exp. Rheumatol. J. 18(21): 87- 92 .

6. Minaur, N.J., Jefferiss, C., Bhalla, A.K. and Beresford, J.N. 2002. Methotrexate in the treatment of rheumatoid arthritis. I. In vitro effects on cells of the osteoblast lineage. Rheumatology; 41: 735- 740.

7. Whittle, S. and Hughes, R. 2004. Folate supplementation and methotrexate treatment in rheumatoid arthritis: a review. Rheumatology 34: $267-271$.

8. Bologna, C., Edno, L., Anaya, J., Canovas, F., Berghe, M.V., Jorgensen, C., Galtier, M., Combe, B., Bressolle, F. and Sany, J. 1994. Methotrexate concentrations in synovial membrane and trabecular and cortical bone in rheumatoid arthritis patients. Arthritis and Rheumatism 37(12): 1770 -1773.

9. Mandel, K., Atkinson, S., Barr, R. and Pencharz, P. 2004. Skeletal morbidity in childhood acute lymphoblastic leukaemia. Clin. Endocrinol. 5: $1215-21$.

10. Van Leeuwen, B.L., Kamps, W.A., Jansen, H.W., and Hoekstra, H.J. 2000. The effect of chemotherapy on the growing skeleton. Cancer Treat. Rev. 26: $363-376$.

11. Fischer, G.S., Neira, L.L., Ferreiro, M.M., et al. 2005. Bone mineral density in leukemic children after completing one month of chemotherapy. Rev. Med. Chil. 133: $71-76$.

12. Wijnands, A. and Burgers, M. 2001. Stress fracture in long term methotrexate treatment for psoriatic arthritis. Ann. Rheum. Dis. 60: 736 -739.

13. Cameron, D.A., Douglas, S., Brown, J.E., and Anderson, R.A. 2010. Bone mineral density loss during adjuvant chemotherapy in premenopausal women with early breast cancer: is it dependent on oestrogen deficiency. Breast Cancer Res. Treat. 123: 805- 814 .

14. Raghu-Nadhanan, R., Skinner, J., Chung, R., Su, Y.W., Howe, P.R. and Xian, C.J. 2013. Supplementation with fish oil and genistein, individually or in combination, protects bone against the adverse effects of methotrexate chemotherapy in rats. PLoS One 8(8): e71592.

15. Raghu-Nadhanan, R., Fan, C.M., Su, Y.W., Howe, P.R. and Xian, C.J. 2014. Fish oil in comparison to folinic acid for protection against adverse effects of methotrexate chemotherapy on bone. J. Orthop. Res. 32(4): $587-96$

16. Bashandy, M. and Elharoun, H. 2014. Histological, histochemical and immunohistochemical study of the Effect of chronic low dose of methotrexate and folinic acid on long bone of adult male guinea pigs. Journal of American Science 10(12): 47 -57.

17. Branca, F. 2003. Dietary phyto-oestrogens and bone health. Proc. Nutr. Soc. 62: 877- 887.

18. Sudo, A., Miyamoto, N., Kasai, Y., Yamakawa, T. and Uchida, A. 2003. Comparison of bone mineral density among residents of a mountain village and a fishing village in Japan. J. Orthop. Surg. 11: 6- 9.

19. Baker, J.F., Walsh, P. and Mulhall, K.J. 2011. Statins a potential role in the management of osteoarthritis? Joint Bone Spine 78: 31- 4

20. Pacheco-Pantoja, E.L and Alvarez-Nemegyei, J. 2014 Statins and osteoporosis: A latent promise. Reumatol. Clin. 10(4): 201-203.

21. Mundy, G., Garrett, R., Harris, S., Chan, J., Chen, D., Rossini, G., Boyce, B., Zhao, M. and Gutierrez, G. 1999. Stimulation of bone formation in vitro and in rodents by statins. Science 286: 1946- 9 .

22. Xu, X., Chen, H., Zhang, X., Zhai, Z., Liu, X., Qin, A and Lu, E. 2014. Simvastatin prevents alveolar bone loss in an experimental rat model of periodontitis after ovariectomy. Journal of Translational Medicine 12: 284:1 -9.

23. Om, A.S. and Shim, J.Y. (2007). Effect of daidzein, a soy isoflavone, on bone metabolism in Cd-treated ovariectomized rats. Acta Biochemica Polonica; 54(3): 641- 646.

24. Drury, R. and Wallington, E. 1980. Carleton Histological techniques, $5^{\text {th }}$ Edition. Oxford University Press. London, New York and Toronto 237.

25. Bancroft, J.B. and Gamble, M. 2002. Theory and Practice of Histological Techniques. $5^{\text {th }}$ edition. Churchill Livingstone 377 -694.

26. Sujatha, K., Srilatha, C., Anjaneyului, Y. and Amaravathi, P. 2011. Lead acetate induced nephrotoxicity in wistar albino rats. A pathological, immunohistochemical and ultrastructural studies. Int J. Pharma. \& Bio. Sci. 2(2): 459 -469. 
27. Peat, J. and Barton, B. 2005. Medical statistics. A Guide to data analysis and critical appraisal. First Edition. Wiley- Blackwell.113- 19

28. Abromowitch, M., Ochs, J., Pui, C., Fairclough, D., Murphy, S. and Rivera, G. 1988. Efficacy of high-dosemethotrexate in childhood acute lymphocytic leukemia: analysis by contemporary risk classifications. Blood 71 (4): 866-69.

29. Brennan, B., Rahim, A., Adams, J., Eden, O. and Shalet, S. 1999. Reduced bone mineral density in young adults following cure of acute lymphoblastic leukaemia in childhood. Br J. Cancer 79: $1859-63$.

30. El-Morsi, A.S., Beshir, S.R., Farag, K., Saber, M. and Hamam, G. 2011. Comparative study on the effect of Vitamin $\mathrm{K}$ versus combined $\mathrm{Ca}$ and vitamin $\mathrm{D}$ administration on the prevention of experimentallyinduced osteoporosis in adult male albino rats. Egyptian Journal of Histology, 2011, 34: 5 -14.

31. Xian, C., Cool, J., Scherer, M., Macsai, C. and Fan, C. 2007. Cellular mechanisms for methotrexate chemotherapy-induced bone growth defects. Bone 41: $842-50$.

32. McGee, J.O., Isaacson, P.G. and Wright, N.A. 1992. Pathology of Systems. In: McGee JO, Isaacson PG and Wright NA, editors. Oxford Textbook of Pathology. Oxford, UK: Oxford University Press. pp. 2019-2024, 2038- 2040.

33. Steiniche, T. 1995. Bone histomorphometry in the pathophysiological evaluation of primary and secondary osteoporosis and various treatment modalities. APMIS Suppl. 103:1 -44.

34. Parfitt, A.M., Mathews, C.H.E. and Villanueva, A.B. 1983. Relationships between surface, volume and thickness of iliac trabecular bone in aging and in osteoporosis. Implications for the microanatomic and cellular mechanisms of bone loss. J. Clin. Invest. 72:1396-1409.

35. Reiner, B. and Bertha, F. 1999. Biopsy interpretation of bone and bone marrow: histology and immunohistology in paraffin and plastic. $2^{\text {nd }} \mathrm{ed}$. New York: Hodder Arnold.

36. Nadhanan, R., Skinner, J., Chung, R., Su, Y. and Howe, P. 2013. Supplementation with fish oil and genistein, individually or in combination, protects bone against the adverse effects of methotrexate chemotherapy in rats. PLOS ONE 8(8): e71592.
37. Xian, C., Cool, J., Scherer, M., Fan, C. and Foster, B. 2008. Folinic acid attenuates methotrexate chemotherapy-induced damages on bone growth mechanisms and pools of bone marrow stromal Cells. Journal of Cellular Physiology 214 (3): 777 -85.

38. Mosekilde, L., Thomsen, J., Mackey, M. and Phipps, R. 2000. Treatment with risedronate or alendronate prevents hind-limb immobilization -induced loss of bone density and strength in adult female rats. Bone 27: 639- 45 .

39. Fan, C., Georgiou, K.R., King, T.J. and Xian, C. 2011. Methotrexate toxicity in growing long bones of young rats: A model for studying cancer chemotherapyinduced bone growth defects in children. Journal of Biomedicine and Biotechnology. Volume 2011, 903097: 1- 8

40. Jia, Y.J., Xu, R.X., Sun, J., Tang, Y. and Li, J.J. 2014. Enhanced circulating PCSK9 concentration by berberine through SREBP-2 pathway in high fat dietfed rats. J. Transl. Med. 12:103.

41. Sadowitz, B., Maier, K.G. and Gahtan, V. 2010. Basic science review: Statin therapy-Part I: The pleiotropic effects of statins in cardiovascular disease. Vasc. Endovascular Surg. 44:241-251.

42. Hanayama, R., Shimizu, H., Nakagami, H., Osako, M.K., Makino, H., Kunugiza, Y., Tomita, T., Tsukamoto, I., Yoshikawa, H., Rakugi, H. and Morishita, R. 2009. Fluvastatin improves osteoporosis in fructose-fed insulin resistant model rats through blockade of the classical mevalonate pathway and antioxidant action. Int. J. Mol. Med. 23: 581 -588.

43. Moon, H.J., Kim, S.E., Yun, Y.P., Hwang, Y.S., Bang, J.B., Park, J.H. and Kwon, I.K. 2011. Simvastatin inhibits osteoclast differentiation by scavenging reactive oxygen species. Exp. Mol. Med. 43:605- 612.

44. Zhang, Y., Bradley, A.D., Wang, D. and Reinhardt, R.A. 2014. Statins, bone metabolism and treatment of bone catabolic diseases. Pharmacol. Res. 88: 53- 61.

45. Reid, I.R. and Hague, W. 2000. Effect of pravastatin on fracture incidence in the lipid study: a randomised controlled trial. J. Bone Miner. Res. 15 1): S225.

46. Ribeiro, D.A., Salvadori, D.M. and Marques, M.E. 2005. Abnormal expression of bcl2 and bax in rat tongue mucosa during the development of squamous cell carcinoma induced by 4-nitroquinoline 1-oxide. Int. J. Exp. Pathol. 86: 375- 381. 
47. Tiberio R, Marconi A, Fila C, et al. 2002. Keratinocytes enriched for stem cells are protected from anoikis via an integrin signaling pathway in a Bcl-2 dependent manner. FEBS Letters 524 (1 -3): 139- 144.

48. Verburg, M., Renes, I.B., Neijer, H.P., et al. 2000. Selective sparing of goblet cells and paneth cells in the intestine of methotrexate-treated rats. Am. J. Physiol. Gastrointest. Liver Physiol., 279: G1037- 47, 2000.

49. Civitelli, R., Armamento-Villareal, R. and Napoli, N. 2009. Bone turnover markers: understanding their value in clinical trials and clinical practice. Osteoporosis Int. 20:853 -51.

50. Pietschmann, P., Resch, H., Krexner, E., Woloszczuk, W. and Willvonseder, R. 1991. Decreased serum osteocalcin levels in patients with postmenopausal osteoporosis. Acta Med. Austriaca. 18(5):114- 6.
51. Watanabe, S., Fukomoto, S., Takeuchi, Y., Nakapo, T. and Fujita, T. 2000. Effects of one year treatment with statins on bone mass and metabolism. J. Bone Miner. Res. 15 (1):S194.

52. Iqbal, J. 2011. Ann enzyme immobilized microassay in capillary electrophoresis for characterization and inhibition studies of alkaline phosphatases" J. Anal. Biochem. 414: 226- 231.

53. Washburn, S., Burke, G, Morgan, T. And Anthony, M. 1999. Effect of soy protein supplementation on serum lipoproteins, blood pressure and menopausal symptoms in perimenopausal women. Menopause 6: 7- 11 .

54. Patel, N., Ghodasara, D. J., Pandey, S., Ghodasara P., Khorajiya J. H., Joshi, B. P. and Dave, C. J. 2014 Subacute toxicopathological studies of methotrexate in Wistar rats. VeterinaryWorld 7: 489 -495. 
الملخص العربى

\section{الدور الوقائى لعقار السيمفيستاتين على اصابات العظام الناتجة عن تعاطى عقار الميثوتريكسيت فى البحئ

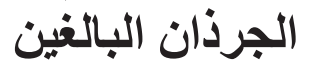

\section{أمجد جابر السعيد و أحمد سمير صادق}

\section{قسم التشريح و الأجنة ـ كلية الطب ـ جامعة عين شمس - مصر}

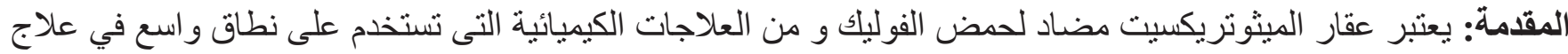

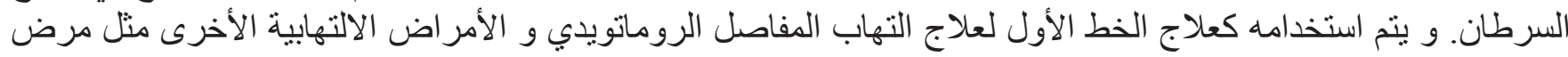

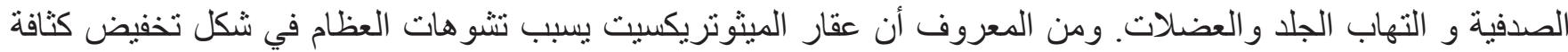

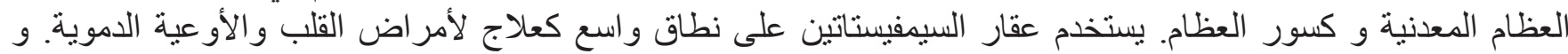

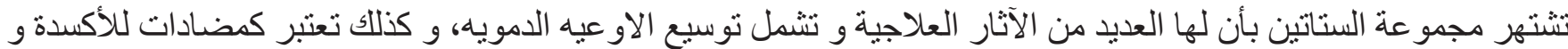
للالتهابات و لها تأثير معدل للعظام. الهُف: : توضيح الدور الوقائى المحتمل لعقار السيمفيستاتين على اصابات العظام الناتجة عن تعاطى عقار الميثوتريكسيت فى الفئران البالغين.

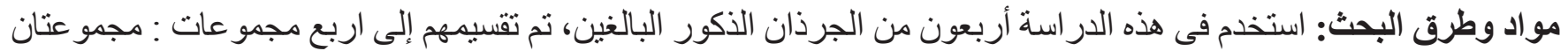

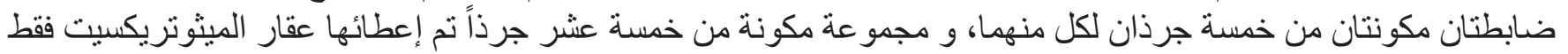

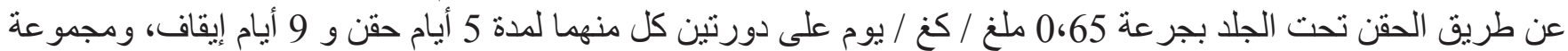

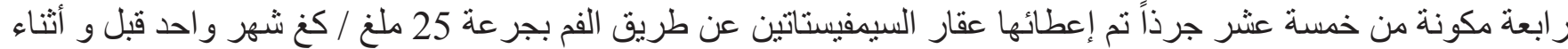

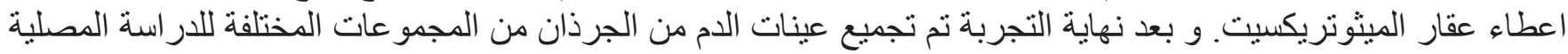

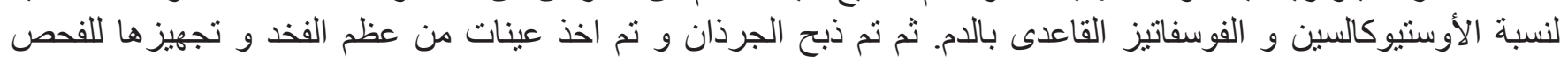

النتائج: أظهر الفحص المجهرى لعظام الجرذان التى أعطيت عقار الميثوتريكسيت فقط وجود نرقق ملحوظ في السمحاق، و و

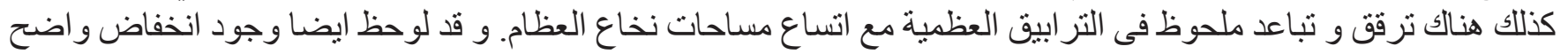

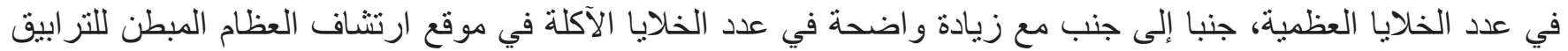

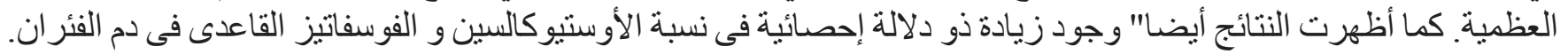

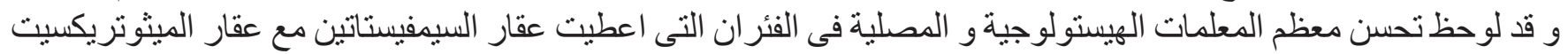
بما في ذلك؛ شكل و تنظيم الخلاياو التر ابيق العظمية، و كذلك عدد كل من الخلايا العظميةو الخلايا الآكلة ونسبة الأوستيو كالسين

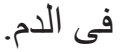
الاستتتاج: إعطاء عقار السيمفيستاتين يعتبر علاجاوقائيا لاصابات العظام الناتجة عن تعاطى عقار الميثوتريكسيت فى الجرذان البالغين. 